\title{
CONSIDERING THE SUB-REGIONAL COOPERATION IN EAST-CENTRAL EUROPE - SOME CONCLUSIONS ON INTEGRATING AND DISINTEGRATING TENDENCIES IN THE SUB-REGIONAL DIALOGUE
}

\author{
Jacek Wieclawski \\ University of Warmia and Mazury in Olsztyn
}

\begin{abstract}
This article discusses the problems of the sub-regional cooperation in East-Central Europe. It formulates the general conclusions and examines the specific case of the Visegrad Group as the most advanced example of this cooperation. The article identifies the integrating and disintegrating tendencies that have so far accompanied the sub-regional dialogue in East-Central Europe. Yet it claims that the disintegrating impulses prevail over the integrating impulses. EastCentral Europe remains diversified and it has not developed a single platform of the sub-regional dialogue. The common experience of the communist period gives way to the growing difference of the sub-regional interests and the ability of the East-Central European members to coordinate their positions in the European Union is limited. The Visegrad Group is no exception in this regard despite its rich agenda of social and cultural contacts. The Russian-Ukrainian conflict confirms a deep divergence of interests among the Visegrad states that seems more important for the future of the Visegrad cooperation than the recent attempts to mark the Visegrad unity in the European refugee crisis. Finally, the Ukrainian crisis and the strengthening of the NATO's "Eastern flank" may contribute to some new ideas of the sub-regional cooperation in EastCentral Europe, to include the Polish-Baltic rapprochement or the closer dialogue between Poland and Romania.
\end{abstract}




\section{Introduction}

The article discusses the sub-regional cooperation in East-Central Europe, its theoretical and practical aspects, institutional dimension, and first of all the integrating and disintegrating tendencies that have so far accompanied the sub-regional dialogue in this part of Europe. It formulates some general conclusions and examines the case of the Visegrad Group as the most advanced example of this cooperation. Considering the concept of East-Central Europe, the paper refers to the post-communist members of the European Union, although the author is aware of some difficulties in the precise delimitation of this area. Similarly, the article follows Eva Cihelková and Pavel Hnát's definition of sub-regionalism as "The situation, where a regional grouping is entirely (or substantially) included within another integration (...)" (Cihelková and Hnát 2006, 51). Thus, it consequently refers to the cooperation in East-Central Europe as the sub-regional dialogue within the broader process of the European integration.

The main thesis of the article is that the disintegrating tendencies within the sub-regional cooperation in East-Central Europe prevail over the integrating impulses. The latter played their principal role during the pre-accession period, yet the Eastern enlargement of the European Union contributed to difficulties with the identification of the new aims in the sub-regional dialogue. It confirmed the incommensurability of the sub-regional cooperation and the dominant process of the European integration as well as growing inability of the East-Central European members of the European Union to coordinate their positions in the EU. East-Central Europe remains diversified and the common experience of the communist period is no longer a factor that could integrate the states in the sub-region. Their interests differ and so far they have not been able to develop a single platform of the sub-regional consultations. Similarly, the EastCentral European members of the European Union have successfully defended the economic interests of the sub-region during the EU's budget debates, but their attitudes towards the main reforms of the European Union are far from united.

The Visegrad Group is no exception in this regard. It is the most advanced sub-regional grouping in East-Central Europe but it suffers similar problems. The Visegrad Group has contributed to the sense of community and mutual understanding among the Visegrad societies, yet the group's political unity has failed and the Russian-Ukrainian conflict confirms a deep divergence of the Visegrad interests. The Visegrad solidarity remains tentative and the difference of opinions among the Visegrad states on the European Union's relations with Russia seems more important for the future cooperation in the Group than its recent unity in the European refugee crisis. In fact, the "Russian factor" may contribute to more serious changes in the sub-regional cooperation in East-Central Europe, including the emergence of the new platforms of the sub-regional dialogue.

This article is divided into three parts. The first discusses contemporary regionalism and the role of East-Central Europe in the sub-regional processes in Europe. Yet its principal aim is to identify the integrating and disintegrating tendencies that accompany the sub-regional dialogue in East-Central Europe. The second section discusses the case of the Visegrad Group as the most advanced forum of this dialogue. It indicates the strengths and weaknesses of the Visegrad 
cooperation, the divergence in the Visegrad attitude towards the Russian-Ukrainian conflict and its consequences for the future course of this cooperation. Finally, the third part of the article outlines new political configurations in the sub-regional cooperation in East-Central Europe that could emerge after the Ukrainian cris is and NATO's recent decisions to strengthen its "Eastern flank", to include the ideas of the Slavkov Triangle or the Polish-Baltic rapprochement.

\section{The Theoretical and Practical Aspects of the Sub-Regional Cooperation in East-Central Europe - Identifying the Disintegrating Tendencies}

The fall of the bipolar order has contributed to a new wave of regionalism in different parts of the world. The "new regionalism" has become a dynamic phenomenon that reflects the processes of globalization, but reaches far beyond the economic and institutional aspects of regional cooperation. As Andrew Hurrell indicates:

“(...) regionalism is an extremely complex and dynamic process founded upon not one but a series of interacting and often competing logics-logics of economic and technological transformation and societal integration; logics of power-political competition; logics of security (both interstate and societal); and logics of identity and community". (Hurrell 2007, 130).

In fact, the new wave of regionalism is still about economics. It is about a coordination of economic interests in the specific environment of global interdependence. Yet the understanding of contemporary regionalism departs from the state-centric, economic-driven or security-oriented perspectives. The post Cold War regionalism reaches beyond the formal and institutional context and emphasises the "soft aspects" of regional processes. They include the role of non-state actors, civic societies, ideas or regional identities (Söderbaum 2012, 14-19; Yi 2007, 5). East-Central Europe is a good example in this regard as the post Cold-War economic transformation and the new liberal identities there are still accompanied by deeply rooted "illiberal" tendencies and social attitudes inherited from the communist past (Wieclawski 2015a, 156-158).

Furthermore, the new wave of regionalism may serve as a collective response to the risks of globalization. It may help to join the global economic processes in a more coordinated way (Hurrel 2007, 130-131; Higgott 2005, 17). Nevertheless, the "new regionalism" does not eliminate the debate on global inequalities and different abilities to participate in the liberalisation of international markets (Hurrell 2007, 144). For less developed states, to include East-Central Europe, it is still a permanent competition for external investment and "participation in that system" (Ethier 1998, 1160; Bleiere 1997, 18). Finally, the new wave of regionalism departs from Euro-centrism and confirms a lack of the single model of this process. Europe remains at its forefront yet the states in Asia or Latin America make their own choices that "(...) best reflect their own needs and the political commitment of the actors involved" (Higgott 2005, 17). 
In a theoretical context the article shares Fredrik Söderbaum's conclusions about the proliferation of theories that accompany the new wave of regionalism. Theorising in the regional studies attracts both the broader approaches typical for International Relations (neoliberal institutionalism, neorealism) and attitudes focused on regional integration processes (neofunctionalism, federalism). It reaches for the new governance theories but also a catalogue of constructivist and post-structural approaches that depart from the mainstream rationalist (positivist) considerations (Söderbaum 2012, 13). The abundance of theories contributes to problems with the "conceptual clarity" and coherence in the analysis of the new regionalism. Nevertheless, the regional studies are no exception in this regard and illustrate a broader debate in the social sciences (and especially International Relations) after the end of the Cold-War about the proliferation of theoretical approaches, fragmentation and hybridity of their disciplines (Waever 2010, 298-303, 315-316; Smith 2010, 4-13).

This article does not aspire to solve these problems yet its author has usually postulated the dialogue between different theoretical attitudes (Wieclawski 2015b, 145-148). Thus, the Chunyao Yi study of the synthesis between rationalist and constructivist approaches in the regional studies seem worth mentioning. Yi urges that both interests and ideas matter in the study of contemporary regionalism and "(...) international society is both material and ideational, in which material incentives and social construction both play indispensable roles" (Yi 2007, 27). Therefore, a search for the bridge between the rationalist and constructivist approaches is useful for the multi-casual study of contemporary regional processes, despite the ontological and methodological differences between them (Yi 2007, 3-4, 8-16, 27-29). The complex interactions between the material and ideational aspects of the liberal and democratic transformation in EastCentral Europe seem to confirm this conclusion and illustrate that any serious explanation of the contemporary regionalism cannot be based on a single theory.

In Europe the fall of the bipolar order contributed to both the new impulses for the regional integration to include the establishment of the European Union and the emergence of the new European sub-regionalism (Törö et al. 2014, 364). The new wave of the sub-regional cooperation in Europe reflected considerable changes in the political, economic and social reality of the continent, to include the transformation of East-Central Europe and the EU's dialogue with the countries on its Mediterranean border. Nevertheless, it has been the democratic and liberal reforms in the post-communist states that serve as a driving-force of the new sub-regional processes in Europe, most of the new sub-regional groupings emerged in East-Central Europe and their dynamic cooperation remains the key to understanding the new sub-regionalism in Europe (Ehier 1998, 1149-1150; Cihelková and Hnát, 2006, 51-52).

Csaba Törő, Eamonn Butler and Károly Grúber consider the sub-regional partnership as “(...) one of the key features of contemporary European politics" (Törő et al. 2014, 364) and Andrew Cottey indicates four functions that the new sub-regional cooperation in Europe has so far served. The first is the bridging one that helps to overcome the historical and political divisions between the members of the sub-regional groups and mitigates possible divisions between the European 
Union and its neighbourhood. The second integrative function reflects the sub-regional cooperation of the East-Central European states in their accession to NATO and the EU. The third function refers to the role of the sub-regional groups as a forum of a common response to transnational challenges, and the fourth illustrates the contribution of the sub-regional dialogue to the East-Central European political and economic transformation (Cottey 2009, 4-5; 13-15).

This article shares the conclusions about the significance of the sub-regional dialogue in contemporary Europe. Nevertheless, it notes that for East-Central Europe the standard media coverage of its effective sub-regional cooperation is more complicated and more nuanced. EastCentral Europe remains a dynamic sub-region on the continent. This dynamism, however, has been accompanied by some fundamental problems, some underlying determinants and some clear impediments. In fact, a deeper analysis of the sub-regional dialogue in East-Central Europe reveals the clash of integrating and disintegrating tendencies and the experience of two decades of this cooperation indicates a growing role of the disintegrating factors. Thus, the next part of this section will identify some fundamental problems in the sub-regional cooperation in EastCentral Europe and some disintegrating tendencies that accompany this cooperation.

First, there are still some difficulties with the identification of the social, cultural, and economic boundaries of East-Central Europe, and problems with the ability of the states in this sub-region to find a common platform of dialogue. East-Central Europe is diverse (Söderbaum 2012, 15) and the sub-regional cooperation in the area remains fragmented. Stefanie Dühr's research on arguments for the European Union's macro-regional strategy for Central Europe may illustrate this conclusion. It indicates that the (sub) region is diverse in terms of geography, economic development, cultural backgrounds and social challenges. Besides, some "sub-spaces" can be identified there that show more coherence and commonality than "the Central European space as a whole" (Dühr 2014, 2, 48). Thus, Dühr concludes that:

“(...) there are currently no clear and convincing arguments for a comprehensive and integrated strategy for the large area of the Central European space. This is because the region is very diverse, and - at the level of Central Europe as a whole - misses a clear transnational rationale or 'core issue' around which cooperation could be structured and which would ensure longer-term political attention" (Dühr 2014, 48).

To be precise, Dühr's concept ofCentral Europe combines the former communist states with the parts of Germany, Austria or Italy and analyses the impact of the previous East-West dividing lines (Dühr 2014, 1-2). Yet even if reduced to the states of the former Eastern bloc alone, these conclusions seem convincing and the differences identified in Dühr's study affect the subregional cooperation in East-Central Europe as well.

In the context of the institutional fragmentation of the East-Central European dialogue there are still different sub-regional groups in the area. Some of them, as the Visegrad Group and the Baltic Council, are "purely sub-regional" and all their participants are the members of the 
European Union. Others, as the Council of the Baltic Sea States, the Central European Initiative or the Carpathian Convention, remain the "peripheral sub-regional groupings" that combine both the members of the EU and the countries on the EU's borders (C ihelková and Hnát 2006, 53-58; Dühr 2014, 3, 39-41). Nevertheless, the states in East-Central Europe permanently lack a single sub-regional platform of dialogue that could gather them together. They even lack a forum for consultations that could help coordinate their positions in the institutions of the European Union. They consult in Brussels before the EU meetings yet these consultations are usually ad hoc and represent different configurations of regional partners - most often the Visegrad Four (V4) or the V4 plus formula (with the participation of Romania or Bulgaria) or, more rarely, the PolishBaltic talks. This fragmentation is remarkable and illustrates both the diversity of East-Central Europe and the limited ability of the sub-regional partners to coordinate their interests.

Second, the evolution of the sub-regional cooperation in East-Central Europe illustrates a gradual loss of significance of the arguments that initially contributed to the sub-regional dialogue. Thus, among the factors that have so far facilitated the cooperation in East-Central Europe this article indicates:

- The common experience of the communist period and similar problems of the transformation after the fall of the bipolar order.

- The escape of the East-Central European states from the post-Soviet zone and their fears that re-emerging Russia may be interested in re-establishing its political and economic influence in the sub-region.

- The escape from the "grey zone" of security that emerged in East-Central Europe at the beginning of the 1990 s.

- The common efforts for democratisation and marked economy transformation combined with the aspirations to join NATO and the European Union.

- Similarity of the level of economic development in the sub-region, although with the acceptance of some differences between the most developed (Czech Republic and Slovenia) and least developed (Romania and Bulgaria) states of East-Central Europe.

- Similarity of the geopolitical position of the states in the sub-region (Brazova, Matczak and Takacs 2013, 10), although with the acceptance of some differences between its northern (Baltic) and southern (Balkan and the Black Sea) parts.

Nevertheless, most of the factors above were crucial at the initial phase of the sub-regional cooperation in East-Central Europe or during the accession negotiations with the European Union. Together with the Eastern enlargements of NATO and the EU their political significance has decreased (Lazar 2014, 28-29).

Third, the Eastern enlargement of the European Union has shifted the core of the political decisions important for East-Central Europe to Brussels. It has contributed to the question of incommensurability of any sub-regional cooperation in Europe and the integration processes in 
the frames of the EU. Eva Cihelková and Pavel Hnát rightly indicate in this regard that the European Union remains the leading scheme of cooperation on the continent, much deeper and certainly more institutionalized than any sub-regional group (Cihelková and Hnát, 2006, 51-52). The dominant position of the EU as the motor of the integration in Europe is unquestionable (Cottey 2009, 5). It does not exclude the space for any sub-regional dialogue, but for the "purely sub-regional groups", existing entirely in the confines of the European Union, "(...) the space for regional cooperation in today's EU is relatively small since it is given by the ability of such groupings to offer to their member states a platform for creating a common position within the decision-making mechanism of the EU" (Cihelková and Hnát 2006, 60-61).

Fourth, the experience of the decade after the Eastern enlargement of the European Union illustrates a limited ability of the states in East-Central Europe to present a common sub-regional response to the most fundamental problems of the EU. It reveals more narrow perspectives (The Visegrad, the Baltic, the Balkan) than a single East-Central European position and again confirms the diversity of the sub-region. So far the East-Central European members of the European Union have had many problems with their coordinated response to the institutional reforms of the EU, the debates on the Constitutional Treaty and the Lisbon Treaty, as well as the economic challenges that the EU faces, including its energy security (Lazar 2014, 30; Strážay 2011, 24-25, 29-31). One of a few exceptions has been the East-Central European solidarity during the European Union's budget debates and its common position in the defence of the level of the EU's financial assistance for the new members (Dangerfield 2008, 653-654). Yet the subregion remains diversified in its attitude to the single European currency since the smaller states in East-Central Europe joined the Euro-zone the others still refrain from this decision.

Similarly, East-Central European members of the European Union emphasise the need of the EU's dialogue with its Eastern neighbourhood yet the Eastern policy of the states in the subregion reflects some differences and particularities. Besides, the Russian-Georgian and the Russian-Ukrainian conflicts confirm the growing divergence of East-Central European interests regarding both political, economic and security aspects of the regional (EU) and sub-regional relations with Russia (Kałan 2013, 1; Marusiak 2015, 37-44; Rácz 2014, 3-8). Finally, even the European refugee crisis has so far been consulted more in the frames of the Visegrad Group, with the ad hoc participation of Romania, Bulgaria or other partners, than in the context of the single and coordinated East-Central European response (Groszkowski 2016).

Thus, the problems discussed above help to identify some more general tendencies that reveal in the East-Central European cooperation and that impede this dialogue. Among the disintegrating trends that could affect the further course of the East-Central European sub-regional cooperation this article emphasises:

- The different historical heritage of the sub-region that had for a long time been a place of conflicting interests of the most powerful European empires (Veselý 2013, 24-25). The communist period muted the historical differences, yet the diverse history of East-Central Europe 
may still determine the shape of the political relations in this part of Europe (Krno 2013, 118119). For example, some countries of the sub-region, including Poland and the Baltic states, share a long and painful experience of the tsarist Russia's domination and their attitude towards contemporary Russia may be different from those in South-Eastern Europe.

- Some cultural differences among the states in the sub-region, despite their similarities. Vera-Karin Brazova, Piotr Matczak and Viktoria Takacs refer in this context to the example of the Visegrad Group and point out that:

"The large difference between the V4 countries is represented by the role of traditionalist values. Especially in the Czech Republic - in contrast with the other three of the V4 countries - the role of secular values is eminent. Comparatively, the Czechs adhere to more self-expression values. This can be related to religiosity. It differs among the V4 countries, with Poland having a high level of adherence to religion (mostly Catholic) and the Czech Republic being one of the least religious countries. Hungary and Slovakia are in between the two" (Brazova, Matczak and Takacs 2013, 11).

- The problem of the leadership in the sub-region. Poland is unquestionably the biggest and potentially the most powerful among the post-communist states in East-Central Europe. It is confirmed by its size, the number of its inhabitants and the nominal GDP of this country that surpasses the GDP of each other partner at least twice. Nevertheless, the quality of life (as illustrated by the HDI index) and the GDP per capita (PPP) of some other states in East-Central Europe (mainly Slovenia and the Czech Republic) exceeds that in Poland and makes the picture of the socio-economic relations in the sub-region more nuanced (UNDP 2013, 143). Hence, even in the frames of the Visegrad Group neither Czech Republic nor Hungary accepts the Polish leadership. Both states do not consider Poland as powerful enough to lead the cooperation in East-Central Europe (Dangerfield 2008, 635, 643; Dangerfield 2014, 77-78).

- The permanent fragmentation of the cooperation in East-Central Europe. The focus on the Visegrad Group does not exhaust the potential of the sub-regional dialogue as it leaves the voices of Romania, Bulgaria, post-Yugoslav and Baltic states unheard. Nevertheless, the lack of the single platform of political consultations in East-Central Europe (as identified earlier) may contribute to growing differences in the perception of the sub-regional problems. The perspectives of Romania and Bulgaria (or Croatia and Slovenia) may considerably differ from that of Latvia and Estonia.

- The domination of the European Union's mechanisms of political consultations and articulation of interests after the accession of the states of East-Central Europe to the EU (Lazar 2014, 28-29). In this pattern of political games, the regional cohesion and solidarity may be valuable in some specific cases. The East-Central European pressure on the wealthiest states of the European Union to keep the previous level of the EU's financial support for the new members may be a good example (Pastwa 2014, 84-85; Jankowski and Grzegrzółka 2014, 9-10). In general, however, the sense of belonging to any sub-region is not the main indication of the political cooperation in the European Union. 
- The growing difficulties with the cohesive East-Central European responses to the fundamental problems of the European Union and limited ability of the countries of the subregion to affect the future course of the EU reforms. The post-communist states in East-Central Europe do not belong to the group of the most powerful members of the European Union. Their support may be important in some political projects yet the political initiative in the EU more often belongs to Germany or France than Poland, Romania or Czech Republic. As a result, a lack of the common proposals of divided and fragmented East-Central Europe may further reduce the political significance of the sub-region.

- The sensitivity of East-Central Europe to the pressure of the external powers, even for the most advanced Visegrad Group, and the fragility of the sub-regional consensus, even in the Eastern policy of the European Union. Besides, as Daina Bleiere notes "A lack of resources and a competition for investments, as well as the attention of the major powers of the world, can weaken any sense of solidarity" (Bleiere 1997, 18).

Thus, discussing the effectiveness of the sub-regional groups in Europe Cottey summarizes that "The impact of European sub-regionalism may not have been dramatic, but a balanced assessment suggests that it has been positive and not entirely insignificant" (Cottey 2009, 20). This conclusion is right, especially in the context of the democratic transformation and the mitigation of the post-Cold War divisions on the continent yet in the sub-regional cooperation in East-Central Europe the initial positive tendencies give way to more complex disintegrating impulses. The next part of the article will discuss the case of the Visegrad Group. It will examine whether the negative trends identified in the East-Central European cooperation reveal in its most advanced sub-regional group.

\section{The Disintegrating Tendencies in the Sub-Regional Cooperation in East-Central Europe - the Case of the Visegrad Group}

Established in 1991 as the informal platform of dialogue of Poland, Hungary and Czechoslovakia (then the Czech Republic and Slovakia) the Visegrad Group has become the most developed forum of cooperation in East-Central Europe. Nevertheless, it is still the more flexible platform for consultations than the international organization, despite some recent attempts to strengthen its organizational capacities (Brazova, Matczak and Takacs 2013, 14-15; Dangerfield 2008, 645). Rick Fawn perfectly indicates in this regard that:

"It is not an institution - although some outside observers mistakenly so claim; and although it possesses some attributes of an intergovernmental organization, such as regularized meetings at all levels of government, an annual high-level summit, a rotating chairmanship with an annual set of goals, and so on, it has never created institutional rules that then force its members to juxtapose cooperation against (supposed) national priority." (Fawn 2010, 504). 
The initial aim of the Visegrad Group was to get experience of the regional dialogue after the fall of the Soviet bloc and in the perspective of the accession to NATO and the European Union (Dangerfield 2014, 72). Its purpose was to convince the new partners in Western Europe that the countries of the Group were credible candidates to join the integration institutions of the West. The slogans of the "return to Europe" were crucial in this regard (Strážay 2011, 15-16) and Milada A. Vachudova rightly concludes that: "Visegrad was first and foremost a triumph of marketing: the term "the Visegrad group" became shorthand for the politically and economically most advanced, most "Western" post-communist states" (Vachudova 2005, 94).

Besides, the countries in the region suffered similar structural problems after the fall of the bipolar order, to include the heritage of the communist past in their social, political, and economic life. The challenges were common and the exchange of views on how to deal with them was reasonable (Brazova, Matczak and Takacs 2013, 2). One of the crucial aspects in this regard was the withdrawal of the Soviet/Russian troops (Strážay 2011, 16-17). After their 50years' presence in the region, it was a symbolic confirmation of the end of the Soviet domination in East-Central Europe. The factor of the external threat was fundamental to the effectiveness of the Visegrad cooperation at its initial phase. Hence, the perspective to join NATO and the European Union was not only the aim of the transformation, but also the escape from the "grey zone" of security between the falling USSR and the West. It was the case of the common protection against the threats that could emerge from unstable and unpredic table post-Soviet area. Finally, it was the prevention from potential Russian attempts to re-establish its political and economic influence in the sub-region.

Nevertheless, the Visegrad cooperation has from the very beginning faced some disintegrating tendencies that contributed to its declarative character and limited effectiveness. The Visegrad dialogue declined together with the division of Czechoslovakia. Slovakia met some problems with the liberal reforms while the Czech Republic remained reluctant to coordinate its position with other states of the Group (Dangerfield 2008, 640; Wolchik 2011, 207). The Czech foreign policy under the Vaclav Klaus premiership believed in the country's advantage and its own capabilities on the path to the European integration (Fawn 2010, 503; Dangerfield 2008, 641642). Thus, the Czech “(...) increase in self-confidence resulted in the conviction that Visegrad co-operation could hold the Czech Republic back (...)" (Strážay 2011, 18-19). The political reality negatively verified the $\mathrm{Czech}$ aspirations, yet the returned tendency in the Czech foreign policy to believe in the country's preponderance over its sub-regional partners became the defining feature of the Visegrad cooperation for at least a decade.

One of the successes of the Visegrad Group during the pre-accession period became the activity of the Central European Free Trade Area (CEFTA). Established in 1992, it contributed to the liberalization of the Visegrad markets (although with some problems in the agricultural goods) and increased the mutual Visegrad trade (Cihelková and Hnát 2006, 59). From the very beginning, however, CEFTA was a short or at best "medium-term" project of the candidate states aspiring to join the European Union and its single market or as Martin Dangerfield concludes, "It 
was a creature of the EU accession process and always had a pre-determined lifespan and an inbuilt limit to its activities" (Dangerfield 2006, 322). Hence, it was clear that together with the accession to the European Union the Visegrad states would leave CEFTA and join the single European market.

In 1998, together with the change of political coalitions in Slovakia and the Czech Republic, the Visegrad Group revived its activity. Besides, the V4 cooperation has departed from its previous political and economic dimension (CEFTA) to include the new area of civic affairs (Gniazdowski 2005, 82; Fawn 2010, 504). The accession negotiations of the Visegrad states with the European Union were full of declarations of their cooperation. The tendencies to cooperate, however, were accompanied by the regional competition and individualistic approaches (Dangerfield 2008, 635, 643; Dangerfield 2014, 77-78). Here, again, the Czech Republic distanced itself from the Polish structural problems with the agricultural sector or the obsolete industry.

Thus, the accession negotiations confirmed both a clash of the integrating and disintegrating impulses in the Visegrad cooperation and the problems with the Visegrad leadership. Poland, as the biggest partner in the Group, has not developed a concept of its effective leadership. It has not had an idea as to how the Visegrad cooperation should work, or how to reach beyond its routine political consultations. On the other hand, neither Czech Republic nor Hungary has accepted the Polish leadership in the sub-region. Both states are too small to aspire to this leadership themselves yet both have not necessarily considered Poland as powerful enough to lead the social, political and economic processes in East-Central Europe (Dangerfield 2008, 635, 643; Dangerfield 2014, 77-78).

The accession of the states from the Visegrad Group to the European Union meant that their initial political goals were achieved. Yet, the Group confirmed in the Kroměŕíz Declaration of May 2004 its will to continue the Visegrad cooperation. The aim of this new phase has been to coordinate the position of the Visegrad states in the European Union as well as strengthen the civil society dimension of the regional cooperation (Strážay 2011, 18; Fawn 2010, 505). One of the specific areas emphasised in the Kroměřiž Declaration has been the focus on the relations with the EU's partners in Eastern Europe and Western Balkans (Dangerfield 2014, 79-83; Lazar 2014, 29). Nevertheless, as Tomáš Strážay indicates “(...) new priorities and goals were formulated very vaguely in the declaration. Although a more precise list of priorities appeared soon in the guidelines of Visegrad cooperation, the lack of an important goal comparable to that of EU accession was still apparent." (Strážay 2011, 23-24).

In practice, the common Visegrad attitude towards the European Union's activities has suffered serious problems and the limited effectiveness of the V4 in the EU's decision making mechanisms has strengthened the declarative character of the Visegrad cooperation. The problems with the common Visegrad position were revealed during the EU Copenhagen summit in 2002, and during the negotiations on the new EU's Constitutional Treaty (i.e., the lack of the Czech, Slovak and Hungarian support for the Polish proposals). The V4 attitude towards the US 
intervention in Iraq was not fully cohesive either (Dangerfield 2008, 647-648; Wolchik 2011, 207-208; Fawn 2010, 504). The Visegrad Four differed in their opinions on the Lisbon Treaty, the EU's energy policy, to include some Polish initiatives in this regard, or the interpretations of the Russian-Georgian conflict (Lazar 2014, 30; Strážay 2011, 24-25, 29-31, Fawn 2013, 345).

One of the few exceptions in this regard has been the Visegrad cooperation around the V4 accession to the Schengen zone and the Visegrad unity in the protection of the economic interests of East-Central Europe during the European Union's budget debates (Törö et al. 2014, 366, 371; Dangerfield 2008, 653-654). The successful pressure on the wealthiest states of the EU, however, was the merit of all East-Central European members of the community and not only the Visagrad Four. In the same vein, the Visegrad Group has launched a dialogue with the partners on the European Union's Eastern neighbourhood, with a special focus on Ukraine and Western Balkans (Lazar 2014, 30; Fawn 2010, 506). The Visegrad states have considerably contributed to the Eastern policy of the EU (to include the activity of the International Visegrad Fund) yet even this consensus did not eliminate the controversies and the elements of competition in the Visegrad cooperation (Gawrich and Stepanov 2014, 13-14). As Dariusz Kałan indicates, “(...) each Visegrad country also pursues its own Eastern policy rooted in a historical and social background, particular economic and geopolitical interests as well as temporary political goals" (Kałan 2013, 1).

The most spectacular, however, has been the lack of Visegrad unity in response to the RussianUkrainian conflict. The Ukrainian crisis has revealed a deep divergence across the Visegrad interests and growing difficulties with the common Visegrad position on the European Union's policy towards Moscow. The attitude of the Visegrad Four towards the Russian Federation has never been fully cohesive (Dangerfield 2014, 85-86; Kałan 2013, 3-6; Marusiak 2015, 46). The Visegrad states have differed in their opinions on the Russian foreign policy and Russia has usually remained outside the official Visegrad agenda (Dangerfield 2012, 966-969). Nevertheless, despite its formal absence in the V4 agenda, the "Russian factor" has accompanied both the Visegrad efforts to join the Euro-Atlantic community and the Visegrad cooperation with the post-Soviet area. In the case of the Russian-Ukrainian conflict, however, it has lost its integration potential and Joerg Forbrig correctly indicates that the Visegrad response to the Ukrainian crisis has considerably departed from the stereotypical picture of East-Central Europe as consistent in its policy towards Russia (Forbrig 2015, 2).

The initial Visegrad unity and its strong support for Ukraine, including the gas "reverse flow" to the Ukrainian system (Marusiak 2015, 37; Forbrig 2015, 4) has given way to the growing difference of interests together with the progress of the Russian-Ukrainian conflict and the European Union's debates on the sanctions on Russia (Rácz 2014, 3; Marusiak 2015, 38-42). The Czech Republic, Hungary and Slovakia emphasised the need of good economic relations with Moscow and feared the negative consequences of the EU sanctions on Russia for their own economies (Gniazdowski et al. 2014, Foy and Byrne 2015). All EU members finally supported 
the sanctions yet some Visegrad states remain reluctant to their further extension (Gniazdowski et al. 2014, Byrne 2014). Dariusz Kałan rightly indicates that:

"The crisis in eastern Ukraine has not changed the Czech Republic, Hungary and Slovakia's perception of their relations with Russia, which continues to be defined primarily through economic and energy cooperation, rather than hard security. Therefore, due to expected financial and political losses, these countries treat with much caution the EU's idea to tighten sanctions against Moscow" (Kałan 2014, 1).

Indeed, the Ukrainian crisis has revealed the scale of the East-Central European energy dependence on Russia two decades after the fall of the USSR (Rácz 2014, 5). Further, it has illustrated the lack of the Visegrad political consistency in relations with Russia (if we consider the Hungarian bilateral contacts with Moscow despite the EU's sanctions). It has confirmed the growing differences of the Visegrad states' perceptions of their fundamental security threats (Gawrich and Stepanov 2014, 15; Marusiak 2015, 43). Finally, András Rácz indicates the clear domestic aspects of the Visegrad response to the Russian-Ukrainian conflict and especially the debate between the political forces supporting the common EU's position and those favouring good contacts with Moscow (Rácz 2014, 6).

Thus, the Ukrainian crisis has further cemented the previous problems within the Visegrad unity. Even if some differences in the Visegrad opinions on Russia have been known before, the recent divergence of the Visegrad interests has never been so deep. Today it practically touches almost all aspects of the Visegrad cooperation. Besides, considering the significance of the EU-Russian relations for the security of the continent, it seems that, in the long term, the difference of the Visegrad states' attitudes towards Russia becomes more fundamental than the previous Visegrad unity during the EU's budget debates. It becomes more important than the recent Visegrad rapprochement in the refugee crisis either. In fact, the more coordinated approach of the Vise grad Four towards the European refugee crisis (Nolan, Philipson and Freeman, 2015) does not necessarily change the picture of their political disunity. The Visegrad voice is important as it reflects the right of the East-Central European members of the European Union to express their independent view on the problem of refugees yet any claims about the Visegrad solidarity in this regard seem premature. The refugee crisis still awaits more decisive solutions that may provoke further tensions in the EU. It may test the Visegrad determination under the greater pressure of European leaders and the more assertive game of interests in the European Union. The experience of the Russian-Ukrainian conflict casts doubt on any future Visegrad unity.

As a result, the Visegrad Group is the example of the advanced cooperation in East-Central Europe that, as Rick Fawn notes, has so far confirmed its "(...) remarkable survivability and transformational capacity" (Fawn 2013, 348). Positive opinions about the Visegrad cooperation emphasise the value of the pre-accession contacts of the Visegrad states, to include the experience of their economic cooperation in CEFTA. They also note the growing sense of community and mutual understanding among the Visegrad societies and the successful civic dimension of the Visegrad Group (Lazar 2014, 30; Fawn 2013, 342). Furthermore, some 
analyses indicate the value of the flexible formula of the Visegrad cooperation and the absence of the predetermined catalogue of problems discussed within its frames. They point out the "soft" and $\grave{a}$ la carte character of the Visegrad activities (Lazar 2014, 40-41; Dangerfield 2008, 657, 661; Törö et al. 2014, 368).

Nevertheless, the Visegrad Group suffers from the same disintegrating tendencies as other subregional groupings in East-Central Europe. First of all, it faces the question of the incommensurability of the Visegrad cooperation with the European Union as the dominant mechanism of the integration on the continent. The Visegrad cooperation will not replace the EU. On the contrary, the emergence of the Visegrad Group was accompanied by the specific "preaccession" logic (Cihelková and Hnát 2006, 53) and the Eastern enlargement of the European Union has illustrated clear difficulties of the Visegrad states to identify their new strategic aims after accession. The Visegrad Group may contribute to some aspects of the sub-regional cooperation in East-Central Europe yet the previous experience of its cooperation, including the reaction to the Russian-Ukrainian conflict, confirm its limited ability to address the fundamental problems of the European Union. Together with the recent economic and institutional cris is of the EU this ability can only decrease and the domination of the disintegrating tendencies over the integrative impulses in the Visegrad cooperation will increase.

Thus, following Rick Fawn's suggestions, any ass essment of the Visegrad cooperation should reflect “(...) an explicit match between expectations and capacities" (Fawn 2013, 340). The Vise grad Group may still be a valuable platform of the sub-regional dialogue that strengthens the social and cultural ties among the Visegrad societies (Fawn 2013, 342). It may also try to keep its pressure on the wealthiest members of the European Union during the EU's budget debates (Pastwa 2014, 84-85; Dangerfield 2008, 632), and it may even achieve some tactical successes in the debate on the European refugee crisis. Nevertheless, the scale of the problems facing the European Union today may confront the Visegrad Group with the challenges that exceed its capacity for further unity and effective cooperation.

\section{The Sub-Regional Cooperation in East-Central Europe - Towards the New Political Configurations?}

The Visegrad Group has been the most advanced forum of consultations in East-Central Europe yet the sub-regional cooperation there is not reduced to Poland, Czech Republic, Slovakia and Hungary. The sub-regional dialogue involves several other groups, including the Central European Initiative or the Council of the Baltic Sea States (Cihelková and Hnát 53-58; Dühr 3, 39-41). Most of them, however, lack the "political ambitions" of the Visegrad Four and focus more on the practical aspects of trans-border cooperation. Besides, the diversity and fragmentation of East-Central Europe has so far contributed to limited and occasional contacts among its different sub-regional groupings. 
Indeed, Daina Bleiere's analysis of the cooperation between the Baltic states and the Visegrad Group in the 1990s notes a lack of stimulating forces and sufficient economic interests, but first of all the focus of both groups on their principal foreign policy aims: the integration with NATO and the European Union. Further, the context of the integration brought about some elements of the Baltic-Visegrad competition, to include the Baltic states' efforts to attract the attention of the Western powers (Bleiere, 11-13, 17-18, 28-33). Thus, Bleiere emphasises that "Historical experience shows that cooperation in Central Europe has most often been induced from the outside. All of the countries of the region need to modernize their economies, but they need some "anchor of modernization" that would facilitate this process. Such an anchor is located outside the region (...)" (Bleiere 27-28). The modernization impulses which are coming more from the process of the European integration than the sub-regional cooperation seem obvious in this regard.

The Eastern enlargement of the EU has not considerably changed the previous lack of dynamism in the Baltic-Visegrad cooperation, with some exceptions of the Polish-Baltic and especially Polish-Lithuanian bilateral contacts. In fact, the similar perceptions of the security risks, the Polish participation in the Baltic Sea cooperation, and the borders with Russia, more strongly encouraged the Polish-Baltic than the Baltic-Visegrad cooperation (Sliwa and Górnikiewicz 2013, 147-152; Bleiere. 4-6, 30-31). Yet even the potential of the Polish-Baltic dialogue was not fully exploited and the most spectacular Polish-Lithuanian projects, including the "energy bridge" (Trubalska, 2014:2-5), were motivated more by the geopolitical and security considerations than the idea of the sub-regional cooperation itself. Thus, Bleiere's conclusion that the cooperation between the Baltic and the Visegrad states could intensify "(...) only if it is backed by simultaneous intensification of the relationship with the EU and NATO itself" still provokes some reflections (Bleyere, 30).

Nevertheless, "the Russian factor", the future course of the European Union's relations with Moscow, and NATO's recent decisions about the strengthening of the Alliance's "Eastern flank" may bring about some new ideas of the sub-regional dialogue. They may strengthen the Polish relations with the Baltic states and, at least from the Polish perspective, contribute to the growing significance of Romania and Bulgaria as the valuable partners in the new sub-regional configurations. Simultaneously the clear difference of opinions on Russia between Poland and other states of the Visegrad Group may encourage Czech Republic, Slovakia and Hungary to search for new political partners in the sub-region. It may strengthen some previous suggestions of the Czech politicians and intellectuals about the country's closer ties with Austria (and Germany) than Poland or the Baltic states (Pehe 2004, Fawn 2013, 341). It does not mean that the new coalitions of interests in East-Central Europe would automatically be more effective than the Visegrad cooperation, yet it indicates a possibility of some new, alternative platforms of the sub-regional dialogue.

In fact, the recent problems with the common Visegrad approach towards Russia encourage the Czech Republic, Slovakia and Austria to engage in a new sub-regional initiative called the 
Slavkov Triangle. The Triangle warns against intensifying conflicts with Moscow and emphasises the significance of the good economic cooperation with Russia. This attitude reflects the interests of the participating states, but it clearly contradicts the political position of Poland (Kałan 2015, 1-2). The idea of the Czech, Slovak and Austrian cooperation is not new. Jiři Pehe claimed in 2004 that the inequality of power in the Visegrad Group and the growing divergence of interests between Poland and its smaller members would contribute to the lack of the "common denominator" in the V4 cooperation. He emphasised that, "After Poland's accession to the EU, other Visegrad countries will be more and more frequently confronted with Polish stances that may not necessarily be in their interests (...)" (Pehe 2004). Thus, "It would be much more natural for the Czech Republic, Hungary and Slovakia to strive for a closer regional cooperation with Austria and Slovenia, the contours of which we can already see in some existing regional groupings" (Pehe 2004).

The Visegrad Group has discussed its expansion to include Austria, Slovenia, Bulgaria or Romania several times during the last two decades. Yet the "Visegrad Four" did not decide on a formal enlargement. Instead, they favoured the so-called V4 plus formula of ad hoc consultations with some other partners in the sub-region. There was no consensus in the Visegrad Group about the potential direction of its extension and, as Tomáš Strážay explains, the enlargement “(...) would complicate the process of decision-making, simply because there would be more opinions and interests to be taken into account" (Strážay 2011, 34). This time, however, the idea of the Czech and Slovak dialogue with Austria is a project of cooperation outside the Visegrad frames. The contours of the Triangle have not yet been finally defined, but it excludes Poland and forms, at least potentially, the alternative to the Visegrad Group (Kałan 2015, 1-2). Thus, if the Slavkov Triangle emerges as a political reality it may reduce the readiness of the $\mathrm{C}$ zech Republic and Slovakia to engage in the Visegrad format. It may deepen the declarative character of the Visegrad cooperation as well.

Furthermore, the crisis in the European Union's relations with Russia and the strengthening of NATO's "Eastern flank" may encourage the new political contacts of Poland and the Baltic states as well as those of Poland and Romania. First of all, the anxiety of the neo-imperial policy of Russia creates a strong incentive for the Polish-Baltic relations, despite the previous declarative character of their partnership. Both partners share similar negative assessment of the Russian foreign policy towards East-Central Europe and postulate further strengthening of NATO's role in the sub-region. Both expect NATO's military presence in their territory and remain suspicious of the new rapprochement between the Western members of the European Union and Russia (Sliwa and Górnikiewicz 2013, 161-167).

The decisions of the NATO Summit in Warsaw in July 2016 are crucial in this regard (Bla ir, 2016). The deployment of NATO's troops in Poland and the Baltic states, including the planned participation of the Polish soldiers in NATO's multi-national battle group in Latvia (Palowski 2016), seems an obvious invitation for both the Polish-Baltic military cooperation and political consultations. Besides, it solves the problem of the lack of the military potential of the Baltic 
partners that has so far made the Polish-Baltic military cooperation difficult. Operating in the multi-national NATO's units Polish and Baltic soldiers could effectively exercise their interoperability and practical cooperation. Finally, NATO's presence in the Baltic Sea area strengthens the question of the Russian Kaliningrad Oblast that borders both Poland and Lithuania. It may further shift the Polish attention to the Baltic cooperation and weaken the subregional dialogue in the Visegrad formula, especially if the previous differences in the Visegrad position on Russia deepen.

Yet, the transformation of the similar Polish-Baltic security concerns into the practical cooperation may face some impediments, despite the clear incentives after the NATO Warsaw Summit. Poland has so far not been the main political partner of the Baltic republics and the latter favoured their economic and political ties with the Nordic states (Opitz 2015, 2-4). Second, the Polish-Lithuanian tensions around the Polish minority, unresolved for the last two decades, could not contribute to this new partnership as well. Finally, the community of the security interests between Poland and the Baltic states does not easily translate into the similarity of opinions on the structural problems of European integration and the potential of the Polish-Baltic cooperation in the European Union still lags behind that of the Baltic-Nordic dialogue (Dudzińska 2013, 4-5, Sliwa and Górnikiewicz 2013, 157-161).

In the same vein, NATO's Warsaw Summit may encourage more dynamic contacts of Poland and Romania (as well as Poland and Bulgaria), despite NATO's limited support for the Romanian postulates to increase the Alliance's presence on the Back Sea area (Szymański and Dąborowski, 2016). Herein, the Russian factor does not play the same crucial role as it does in the Polish-Baltic cooperation yet the strengthening of the NATO's Eastern Flank may contribute to the Polish-Romanian (and the Polish-Bulgarian) political and military relations. The planned participation of the Polish military aircrafts in NATO's Air Policing mission to Romania and Bulgaria, and the possible presence of Romanian troops in NATO's battle group deployed in Poland, seem important in this context (Szymański and Dąborowski, 2016).

Nevertheless, Polish-Romanian relations are an example of the potential of cooperation that has so far not been converted into practical outcomes. Poland and Romania are the biggest and the most populous states in East-Central Europe. Both have become the main US political partners in the sub-region and both strive for a stronger NATO's military presence in East-Central Europe (Balcer 2014). Their practical cooperation, however, has so far not gone beyond the occasional political consultations. Further, the isolation of Romania during the communist period and the initial Romanian (and Bulgarian) problems with the liberal transformation (Vachudova 2005, 3739) meant that Poland and Romania, close allies during the interwar period, do not practically know each other today. 
Finally, both states do not share the common border and both focus on slightly different areas in the sub-region. For Poland, the Baltic Sea is the political priority while for Romania the Black Sea is the natural area of interest. This may not necessarily be the obstacle for the future PolishRomanian cooperation yet the more dynamic development of the Polish-Baltic dialogue seems a bit more likely scenario than the Polish-Romanian (and the Polish-Bulgarian) partnership.

\section{Conclusion}

East-Central Europe has actively joined the new wave of regionalism after the fall of the bipolar order. The dynamic transformation in this part of Europe has confirmed the multifaceted character of this process and illustrates that any serious analysis of the regional affairs must reach beyond the purely economical and institutional perspective. Besides, regional studies cannot be contained in the confines of a single theory and the dialogue between different theoretical approaches better reflects the complex character of contemporary regionalism. Furthermore, the cooperation of the former communist states in East-Central Europe has become the core of the sub-regional processes in Europe that enrich European integration. The subregional cooperation is a stable and valuable element of the political, social and economic landscape of contemporary Europe.

Nevertheless, the sub-regional dialogue in East-Central Europe has from the very beginning been accompanied by the structural problems as well as the clash of the integrating and the disintegrating tendencies. At the initial stage, the aspirations of the states in the sub-region to join NATO and the European Union, and the progress of their liberal reforms, strengthened the positive impulses. Yet the East-Central European states have not been able to develop a single platform of cooperation and the sub-regional dialogue remains fragmented. Besides, the experience of the previous communist period could no longer serve as the unifying factor and the fall of the bipolar order revealed the difference of interests across the sub-region.

The Eastern enlargement of NATO and the European Union marked a fundamental change in the post-Cold War history of East-Central Europe. In many cases, however, the enlargement has confirmed the specific "pre-accession" character of the sub-regional cooperation and strengthened its previous destructing tendencies. It has shifted the core of the decisions important for the sub-region to Brussels. The East-Central European states declared the will to coordinate their positions in the EU's decision making mechanisms yet the practical results of this coordination has been limited. They have been able to defend the economic interests of the subregion during the EU's budget debates yet their attitudes to the most fundamental problems of the EU have differed. Besides, the recent institutional and economic crisis in the European Union and the problems with the EU-Russian relations strengthen the previous difficulties in the subregional dialogue.

The Visegrad Group is no exception in this regard. It has been the most advanced group in the sub-regional cooperation yet it faces the same negative tendencies as other sub-regional 
groupings in East-Central Europe. The Visegrad states have not been able to coordinate their attitudes towards the main reforms of the European Union and the Ukrainian crisis illustrates the deep divergence of the Visegrad interests both in the bilateral relations with Russia and the EU's cooperation with Moscow. As Petr Robejšek notes the Visegrad Group has never recovered from the "excessive romanticism" and "(...) remains an unacceptable balance between vision and illusion" (Robejšek 2001, 10).

The Visegrad cooperation has gradually been losing its dynamics and the recent revival of the Visegrad unity in the European refugee crisis does not change this picture. Instead, the idea of the Slavkov Triangle reveals a threat of the marginalization of the Visegrad dialogue. Milada Anna Vachudova warns against the split among the states in the sub-region on the "Cosmopolitan Central Europe", which is more dynamic in international affairs and engaged in European integration, and the "Provincial Central Europe", that is more sceptical towards the future of the EU and less active within the international forum (Vachudova 2001, 13-14). Further, the recent Russian-Ukrainian conflict and NATO's decisions about the strengthening of its "Eastern flank" may contribute to some new political configurations in the sub-regional cooperation, mainly the Polish-Baltic rapprochement in the security affairs and, less likely, the dialogue between Poland and Romania (or Poland and Bulgaria).

Thus, the future course of the sub-regional cooperation in East-Central Europe still depends on the partners' determination to participate in this process (Marušiak 2013, 12) and there are still some arguments in favour of the sub-regional dialogue, especially to reduce its "ambitions" to the areas of civic society or trans-border cooperation. Yet the experience of the last two decades confirms the main thesis of the article that the disintegrating tendencies in the sub-regional cooperation in East-Central European outweigh its integrating impulses.

\section{References}

Balcer, Adam. "The Ukrainian Policy of Poland and Romania," Aspen Review, no.3, (2014): 1-3. http://www.aspeninstitute.cz/en/article/3-2014-the-ukrainian-policy-of-poland-andromania Accessed 22 January 2016.

Blair, David. "Why Nato's Warsaw summit is the most significant since the Cold War," The Telegraph, 7 July 2016.

Bleiere, Daina. "Cooperation of the Baltic States with the Visegrad Countries: Security Aspects," NATO Fellowship Final Report, 26 June 1997, 1-35. http://www.nato.int/acad/fellow/95-97/bleiere.pdf Accessed. 08 July 2016.

Brazova, Vera-Karin, Piotr Matczak and Viktoria Takacs. Regional Organization Study: Visegrad Group. Poznań: Adam Mickiewicz University, 2013. 
Byrne, Andrew. "Hungary questions EU sanctions on Russia," Financial Times, 16 October 2014.

Cihelková, Eva and Pavel Hnát. "Subregionalism Within the EU with Special Regard to the Groupings of which the Czech Republic is a Member," Prague Economic Papers, Vol. 15, No. 1 (2006): 50-62.

Cottey, Andrew. "Sub-regional Cooperation in Europe: An Assessment," Bruges Regional Integration \& Global Governance Papers, No. 3 (2009): 1-24.

Dangerfield, Martin. "Subregional Integration and EU Enlargement: Where Next for CEFTA?," JCMS: Journal of Common Market Studies 44, no. 2, (2006,): 305-324.

. "The Visegrád Group in the Expanded European Union: From Preaccession to Postaccession Cooperation," East European Politics and Societies 22, no. 3 (2008): 630667.

. "Visegrad Group Co-operation and Russia," JCMS: Journal of Common Market Studies 50, no. 6 (2012): 958-974.

. "V4: A new brand for Europe? Ten years of post-accession regional cooperation in Central Europe," Poznań University of Economics Review 14, no. 4 (2014): 71-90.

Dudzińska, Kinga. "The Baltic States' Success Story in Combating the Economic Crisis: Consequences for Regional Cooperation within the EU and with Russia," PISM Policy Paper 54, no. 6 (2013): 1-6.

Dühr, Stefanie. "Are there arguments for a Central European macro-regional strategy?" INTERREG IVB Central Europe 'City-Regions' project, Final report, Radboud University Nijmegen, November 2014, 1-57. http://repository.ubn.ru.nl/bitstream/handle/2066/133786/133786.pdf?sequence=1 Accessed, 04 July 2016.

Ethier, Wilfred J. "The New Regionalism," The Economic Journal 108, no. 449, (1998): 11491161.

Fawn, Rick. "Regional security and regional relations." In Sabrina P. Ramet (ed.) Central and Southeast European Politics since 1989, Cambridge-New York: Cambridge University Press, 2010, 495-518.

. "Visegrad: Fit for purpose?," Communist and Post-Communist Studies 46, no. 3, (2013): 339-349.

Forbrig, Joerg. "Introduction: A Region Disunited?" In Joerg Forbrig (ed.) A Region Disunited? Central European Responses to the Russia-Ukraine Crisis, The German Marshall Fund of the United States, Europe Policy Paper, No. 1, 2015, 2-6. 
Foy, Henry and Andrew Byrne. "Russia sows discord in central Europe," Financial Times, 19 March 2015.

Gawrich, Andrea and Maxim Stepanov. "German Foreign Policy toward the Visegrad Countries. Patterns of Integration in Central Europe," The German Council on Foreign Relations, DGAPanalyse, no. 17, (2014): 1-20.

Gniazdowski, Mateusz, Jakub Groszkowski and Andrzej Sadecki. "A Visegrad cacophony over the conflict between Russia and Ukraine," The Centre for Eastern Studies (OSW), Analyses, 9 October 2014, 1-5.

http://www.osw.waw.pl/en/publikacje/analyses/2014-09-10/a-vise grad-cacophony-overconflict-between-russia-and-ukraine Accessed 2 February 2016.

Gniazdowski, Mateusz. "Possibilities and Constraints of the Visegrád Countries Cooperation within the EU," Foreign Policy Review, no. 1-2 (2005): 77-96.

Groszkowski, Jakub. "Behind the scenes of plan B: the migration crisis seen from the perspective of the Visegrad Group,” OSW Analyses, February 172016.

Higgott, Richard. "The Theory and Practice of Global and Regional Governance:

Accommodating American Exceptionalism and European Pluralism," GARNET Working Paper, no. 01/05, November 2005, 1-32.

http:/www2.warwick.ac.uk/fac/soc/pais/research/researchcentres/csgr/garnet/workingpap ers/0105.pdf Accessed 12 July 2016.

Hurrell, Andrew. "One world? Many worlds? The place of regions in the study of international society," International Affairs 83, no. 1 (2007): 127-146.

Jankowski, Dominik P. and Małgorzata Grzegrzółka. „Toward an Effective Minilateralism: The Polish Experience in the Visegrad Group after 2004," The German Council on Foreign Relations, DGAP analyse, no. 8, May 2014, 1-27.

Kałan, Daruisz. East of Centre: Can the Visegrad Group Speak with One Voice on Eastern Policy?" The Polish Institute of International Affairs, Policy Paper 53, no. 5, (2013): 110.

. "To Have or to Be: The Dilemma of EU Sanctions on Russia for the V4," The Polish Institute of International Affairs, Bulletin 113 (708), 11 September 2014, 1-2. . "The Slavkov Triangle: A Rival to the Visegrad Group?" The Polish Institute of International Affairs, Bulletin, no. 19 (751), 16 February 2015, 1-2.

Krno, Svetozár. "V4 at a Crossroad?" In Juraj Marušiak et al. Internal Cohesion of the Visegrad Group, Bratislava: Institute of Political Science, Slovak Academy of Sciences (2013): 117-121. 
Lázár, András Máté. "Post-Eu-Accession Visegrád Cooperation - Results, Rhetoric, Prospects," BiztPol Affairs 2, no. 1, (2014): 22-44.

Lazarova, Daniela. "Czech-Polish food war back in the spotlight" Radio Prague, 9 December 2014. http://www.radio.cz/en/section/business/czech-polish-food-war-back-in-the-spotlight Accessed 29 October 2015.

Marusiak, Juraj. "Introduction” In Juraj Marušiak et al. Internal Cohesion of the Visegrad Group, Bratislava: Institute of Political Science, Slovak Academy of Sciences. 2013, 10-14.

. "Russia and the Visegrad Group - more than a foreign policy issue, International Issues \& Slovak Foreign Policy Affairs 24, no. 1-2 (2015): 28-46.

Nolan, Dan, Alice Philipson and Colin Freeman. "Eastern bloc to stand firm against EU migrant quotas," The Telegraph, 20 September 2015.

Opitz, Christian. "Potential for Nordic-Baltic Security Cooperation," German Institute for International and Security Affairs, Comments, no. 40, August 2015, 1-4.

Palowski, Jakub. "Polish Soldiers Will Be Deployed To Baltic Republics," Defence 24.pl , 17 March 2016. http $/ /$ www.defence24.com/327709, polish-soldiers-will-be-deployed-to-balticrepublics Accessed 21 July 2016.

Pastwa, Jan. "The Role of the Visegrad Cooperation in EU Foreign Relations," Pro Publico Bono - Magyar Közigazgatás, no. 3 (2014): 83-90.

Pehe, Jirí. "Is the End of Visegrád in the offing?" 18 February 2004. http://www.pehe.cz/Clanky/2004/02-18-visegrad.html Accessed 19 October 2015.

Rácz, András. "Divided Stands the Visegrad? The V4 have been united towards the Ukraine crisis but remain split concerning Russia," The Finnish Institute of International Affairs, FIIA Briefing Paper, no. 158, June 2014, 1-8.

Robejšek, Petr. "Between Vision and Illusion," The New Presence. The Prague Journal of Central European Affairs 3, No. 3, (2001): 10-11.

Sliwa, Zdzislaw and Marcin Górnikiewicz. "Security Cooperation Between Poland and The Baltic Region," Baltic Security \& Defence Review 15, no. 2 (2013): 146-182.

Söderbaum, Fredrik. "Theories of Regionalism." In Mark Beeson and Richard Stubbs (eds.) The Routledge Handbook of Asian Regionalism, London and New York: Routledge, 2012, 1121. 
Strážay, Tomáš. "Visegrad - Arrival, Survival, Revival: In Břetislav Dančák et al. (eds.) Two Decades of Visegrad Cooperation: Selected V4 Bibliography, Bratislava: International Visegrad Fund (2011): 14-38.

Szymański, Piotr and Tomasz Dąborowski. „NATO’s Eastern Flank - a new paradigm,” OSW Analyses, July 132016.

Törő, Csaba, Eamonn Butler and Károly Grúber. "Visegrád: The Evolving Pattern of Coordination and Partnership After EU Enlargement," Europe-Asia Studies 66, no. 3, (2014): 364-393.

Trubalska, Justyna. "The significance of the Polish-Lithuanian energy cooperation for the EU," Pulaski Policy Papers, no. 6 (2014):1-5.

UNDP. Human Development Report 2013. The Rise of the South: Human Progress in a Diverse World, New York: United Nations Development Programme, 2013.

Vachudova, Milada A. "The Division of Central Europe," The New Presence. The Prague Journal of Central European Affairs 3, no. 3, (2001): 12-14.

. Europe Undivided. Democracy, Leverage, and Integration After Communism, Oxford: Oxford University Press, 2005.

Veselý, Zdeněk. "Historical Dimension of Mutual Relationships of Visegrad Members". In Juraj Marušiak et al. Internal Cohesion of the Visegrad Group, Bratislava: Institute of Political Science, Slovak Academy of Sciences, 2013, 15-34.

Wieclawski, Jacek. "Considering the Rapprochement of Realism and Liberalism in Contemporary International Relations - Some Conclusions in the Context of the Russian Foreign Policy," Scottish Journal of Arts, Social Sciences and Scientific Studies 25, no.2, (2015): 140-152.

- "The Gap between the Liberal Rhetoric and the Socio-Political Reality of Contemporary International Relations" - the Example of East-Central Europe," Central-European Political Studies, no. 2 (2015): 151-165.

Wolchik Sharon L. "The Czech and Slovak Republics. Two Paths to the Same Destination". In Sharon L. Wolchik and Jane L. Curry (eds.) Central and East European Politics. From Communism to Democracy, Lanham-Plymouth: Rowman \& Littlefield Publishers, Inc., 2011, 187-211.

Yi, Chunyao. "Emergence of Regionalism: About State Preference Formation," POLIS Working Paper (School of Politics and International Studies, University of Leeds), no. 23, January 2007, 1-36 http://www.polis.leeds.ac.uk/assets/files/research/working-papers/wp23yi.pdf Accessed 07 July 2016. 
Published by the Centre for European Studies at Carleton University, Ottawa, Canada Available online at: journals.carleton.ca/rera/index.php/rera

RERA is an electronic academic peer-reviewed journal. Topics relate to the European Union, its Member States, the former Soviet Union, and Central and Eastern Europe. The journal is a joint project supported by the Canada-Europe Transatlantic Dialogue-a cross-Canada research network supported by the Social Sciences and Humanities Research Council of Canada (SSHRC) - along with the Institute of European, Russian and Eurasian Studies (Carleton University) and its associated research unit, the Centre for European Studies.

RERA aims to provide an accessible forum for research, to promote high standards of research and scholarship, and to foster communication among young scholars.

\section{Contact:}

Carleton University

The Centre for European Studies

1103 Dunton Tower

1125 Colonel By Drive

Ottawa, ON K1S 5B6

Canada

Tel: +01 613 520-2600 ext. 3117; E-mail: rera-journal@ carleton.ca

\section{Creative Commons License}

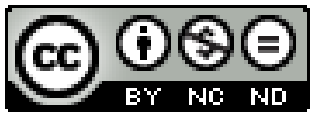

creativecommons.org/licenses/by-nc-nd/3.0

This Working Paper is licensed under a Creative Commons Attribution-Non-CommercialNo Derivs 3.0 Unported License (CC BY-NC-ND 3.0).

Articles appearing in this publication may be freely quoted and reproduced, provided the source is acknowledged. No use of this publication may be made for resale or other commercial purposes.

ISSN: $1718-4835$

(C) 2016 The Author(s) 